\title{
PENINGKATAN SELF EFFICACY MATEMATIS MELALUI PEMBELAJARAN KOOPERATIF TIPE TWO STAY TWO STRAY BERBASIS AUTOGRAPH
}

\author{
Ramadhani' , Eryanti Lisma² \\ 1 Universitas Muslim Nusantara Al-Washliyah \\ 2 Universitas Muslim Nusantara Al-Washliyah \\ ramah.math@gmail.com, yantilisma3003@gmail.com
}

\begin{abstract}
ABSTRAK Universitas Muslim Nusantara AI Washliyah sudah memiliki lisensi Autograph. Namun, masih ada mahasiswa yang belum mengenal atau menggunakan software Autograph. Oleh karena itu, mahasiswa perlu diajarkan dengan software Autograph yang dapat mempermudah dalam proses belajar mengajar khususnya pada mata kuliah Geometri Analitik Bidang. Pembelajaran kooperatif tipe two stay two stray (TSTS) merupakan salah satu pembelajaran yang menuntut mahasiswa lebih aktif. Dalam pembelajaran TSTS mahasiswa terdiri dari 2 orang yang tinggal di kelompoknya dan 2 menjadi tamu ke kelompok lain. Dengan pembelajaran kooperatif tipe TSTS berbasis Aoutograph dapat meningkatkan self efficacy matematis. Metode penelitian ini adalah quasi eksperimen. Populasi dalam penelitian ini adalah mahasiswa semester III Pendidikan Matematika di Universitas Muslim Nusantara Al Washliyah dan sampenya 30 orang mahasiswa. Instrumen yang digunakan dalam penelitian ini adalah angket self efficacy matematis. Analisis dalam penelitian ini akan di analisis dengan uji t. Berdasarkan hasil penelitian ini diperoleh nilai t hitung 3,479 lebih dan † tabel 2,003. Karena t hitung lebih besar dari † tabel, maka terdapat peningkatan self efficacy matematis dengan pembelajaran kooperatif tipe two stay two stray berbasis Autograph.
\end{abstract}

Kata-kata Kunci: Self Efficacy Matematis, Pembelajaran Kooperatif, Two Stay Two Stray, Autograph

\section{PENDAHULUAN}

Salah satu Misi dari program studi pendidikan matematika Universitas Muslim Nusantara (UMN) Al Washliyah adalah untuk mengahasilkan Sarjana Pendidikan Matemtika yang unggul, berkualitas dan islami. Untuk mewujudkan Misi tersebut UMN Al Washliyah telah memberikan fasilitas pembelajaran yang memadai. Salah satunya adalah telah memiliki lisensi software Autograph. Sehingga mahasiswa dapat mempelajari software tersebut dan dapat mengaplikasikannya ketika menjadi guru matematika di sekolah. Hal ini sesuai dengan pendapat Simanjuntak (2017) Autograph sangat dibutuhkan oleh pendidik matematika dalam menghadapi Masyarakat Ekonomi Asia (MEA) yang menuntut kreativitas dari seorang pendidik matematika.

Namun kenyataanya, masih ada mahasiswa UMN AI Washliyah yang belum pernah mengenal atau mempelajari software Autograph. Oleh karena itu peneliti 
menggunakan software Autograph dengan metode pembelajaran kooperatif tipe two stay two stray (TSTS) dalam mata kuliah Geometri Analitik Bidang.

Metode pembalajaran koopertif tipe TSTS adalah pembelajaran berkelompok yang terdiri dari 4 orang mahasiswa. Setelah diskusi dalam kelompok, mahasiswa dibagi 2 orang menjadi tamu ke kelompok lain dan 2 tetap tinggal di dalam kelompoknya. Mahasiswa yang tinggal di dalam kelompok bertugas menjelaskan hasil diskusinya kepada tamu yang dating. Dan mahasiswa yang menjadi tamu bertugas menyatat dan menganalisis hasil diskusi kelompok yang di kunjungi, kemudian menjelaskan kembali kepada teman di kelompoknya.

Pembelajaran kooperatif tipe TSTS merupkan salah satu pembelajaran yang dapat meningkatkan kemampuan pemecahan masalah dan self efficacy matematis Hal ini, sesuai dengan penelitian-penelitian terdahulu seperti: (1) Penelitian Suraji \& Sari (2017), penerapan model kooperatif tipe TSTS dapat meningkatkan kemampuan pemecahan masalah matematis siswa kelas V SD Negeri 136 Pekanbaru, (2) Penelitian Ramadhani \& Sidabalok (2018), terdapat pengaruh yang positif antara pembelajaran kooperatif tipe two stay two stray terhadap self efficacy matematis, (4) Penelitian Ananda \& Novita (2018), model pembelajaran kooperatif tipe two stay two stray untuk melatihkan self efficacy didapatkan persentase rata-rata sebesar 88\% pada pertemuan pertama, $96 \%$ pada pertemuan kedua dan $100 \%$ untuk pertemyan ketiga.

Self-efficacy merupakan aspek psikologis yang memberikan pengaruh signifikan terhadap keberhasilan siswa dalam menyelesaikan tugas dan pertanyaanpertanyaan pemecahan masalah dengan baik (Jatisunda, 2006). Sedangkan menurut Ormrod adalah penilaian seseorang tentang kemampuannya sendiri untuk menjalankan perilaku tertentu atau mencapai tujuan tertentu (Sanjaya, 2006). Dengan demikian, self efficacy matematis adalah kepercayaan diri terhadap kemampuan yang dimilikinya dalam menyelesaikan masalah matematika.

Sehingga self efficacy matematis merupakan salah satu faktor penting dalan meningkatkan kemampuan matematis siswa, khusunya kemampuan pemecahan masalah matematik. Hal ini sesuai dengan penadapat Jatisunda (2006) yang menyatakan bahwa, jika sesorang siswa memiliki kemampuan pemecahan masalah matematis yang baik maka seorang siswa tersebut memiliki self-efficacy yang baik pula. Menurut Bandura (dalam Subiadi, 2016:64), siswa yang memiliki Self-Efficacy rendah mengalami kesulitan dalam memecahkan tugas dan menganggap tugas tersebut sebagai ancaman terhadap dirinya. Dengan demikian siswa yang memiliki jika siswa memiliki kemampuan matematis yang baik maka self efficacy matematis juga baik, sebaliknya jika siswa memiliki kemampuan matematis yang rendah maka self efficacynya juga rendah.

Pembelajaran kooperatif merupakan pembelajaran kelompok/diskusi. Dengan pembelajaran ini siswa dapat berinterasi atau bertukar pendapat mereka seputar pelajaran. Pembelajaran ini sangat baik diterapkan dalam proses pembelajaran. Menurut Salvin (dalam Sanjaya, 2006) mengemukakan, "Dua alasan, pertama, beberapa hasil penelitian membuktikan bahwa penggunaan pembelajaran koopertif dapat meningkatkan prestasi belajar siswa sekaligus dapat meningkatkan 
kemampuan hubungan sosial, menumbuhkan sikap menerima kekurangan diri dan orang lain. Kedua, pembelajaran kooperatif dapat merealisasikan kebutuhan siswa dalam belajar berpikir, memecahkan masalah, dan mengintegrasikan pengetahuan dengan keterampilan".

Pembelajaran kooperatif memiliki banyak tipe salah satunya two stay two stray (TSTS) atay Dua Tinggal Dua Tamu. Tujuan dalam pembelajaran kooperatif tipe TSTS adalah melatih siswa bekerja sama dalam kelompoknya dan meningkatkan kepercayaan diri dalam menjelaskan materi atau hasil diskusi kepada teman dalam kelompoknya atau kelompok lain (tamu). Langkah-langkah pemeblajaran kooperatif tipe TSTS menurut Istarani (2011) adalah:

a) Peserta didik bekerja sama dalam kelompoknya yang berjumlah 4 (empat) orang.

b) Setelah selesai, dua orang masing-masing menjadi tamu di kelompok lain.

c) Dua orang yang tinggal dalam kelompok bertugas membagikan hasol kerja dan informasi ketamu mereka.

d) Kelompok mencocokkan dan membahas hasil kerja mereka

Autograph menurut Karnasih (2008), merupakan salah satu software yang digunakan dalam pembelajaran matematika. Software autograph adalah salah satu media yang dapat digunakan dalam mempelajari tentang dua dimensi, tiga dimensi, statistik, transformasi, geometri, persamaan, koordinat, differensial, grafik, aljabar dan lain-lain. Dengan adanya software Autograph dapat mempermudah pembelajaran matematika. Penggunaan Autograph membantu guru dalam membuat siswa memiliki perhatian penuh terhadap papan tulis interaktif dan bertindak sebagai media interaksi antara siswa atau antara guru dan siswa dengan respon cepat (Simanjuntak, 2017).

Dengan demikian, langkah-langkah pembelajaran kooperatif tipe two stay two stray berbasis Autograph dalam penelitian ini adalah:

1. Membentuk kelompok terdiri dari 4 orang secara heterogen.

2. Mahasiswa berdiskusi di dalam kelompok dengan menggunakan software Autograph untuk menyelesaikan masalah yang diberikan.

3. Dua orang setiap kelompok menjadi tamu ke kelompok lain. Dan dua orang tinggal di dalam kelompok.

4. Mahasiswa yang tinggal di dalam kelompoknya bertugas memberikan hasil diskusi dengan menunjukkan hasil yang diperoleh dengan software Autograph kepada tamu.

5. Mahasiswa yang menjadi tamu kembali ke kelompoknya masing-masing dan memberikan hasil atau informasi kepada teman dalam kelompoknya.

Dengan demikian langkah-langkah pembelajaran kooperatif tipe TSTS berbasis Autograph seperti langkah-langkah di atas. Sehingga setiap mahasiswa dituntut aktif dan paham menggunakan software Autograph supaya pembelajaran dapat perjalan dengan baik. Dosen sebagai pembimbing bertugas membimbing kelompok yang mengalami kesulitan dalam diskusi. 


\section{METODE}

Penelitian ini bertujuan untuk mengetahui peningkatan self efficacy matematis dengan memberikan pembelajaran kooperatif tipe TSTS berbasis Autograph. Penelitian eksperimen merupakan metode penelitian yang dilakukan untuk mencari pengaruh treatment (perlakuan) tertentu (Sugiyono, 2017). Penelitian eksperimen yang dilakukan pada penelitian ini adalah penelitian eksperimen semu (quasi eksperiment).

Populasi penelitian ini adalah mahasiswa semester III Program Studi Pendidikan Matematika UMN AI Washliyah. Sampel penelitian terdiri dari 30 mahasiwa semester III Program Studi Pendidikan Matematika UMN AI Washliyah. Penelitian di laksanakan pada Semester Ganjil Tahun Ajaran 2018/2019.

Instrumen yang digunakan dalam penelitian adalah angket self efficacy matematis. Pemberian skor setiap pilihan dari pernyataan skala self-efficacy berdasarkan pedoman penskoran pada tabel 1 di bawah ini.

Tabel 1. Skor Alternatif Jawaban skala Self-Efficacy

\begin{tabular}{lclc}
\multicolumn{1}{c}{ Pernyataan positif } & \multicolumn{2}{c}{ Pernyataan Negatif } \\
\hline \multicolumn{1}{c}{ Alternatif Jawaban } & Skor & \multicolumn{1}{c}{ Alternatif Jawaban } & Skor \\
\hline Sangat Setuju & 4 & Sangat Setuju & 1 \\
\hline Setuju & 3 & Setuju & 2 \\
\hline Tidak setuju & 2 & Tidak setuju & 3 \\
\hline Sangat tidak setuju & 1 & Sangat tidak setuju & 4 \\
\hline
\end{tabular}

Analisis deskriftif yaitu menghitung persentasi mahasiswa yang memperoleh skor 4, 3, 2, dan 1 dari hasil self efficacy matematik setiap indikator baik data sebelum dan sesudah pembelajaran TSTS. Selanjutnya menghitung nilai indeksnya dengan rumus:

Keterangan:

$$
\text { Nilai Indeks }=\frac{\left(F_{1} \times 1\right)+\left(F_{2} \times 2\right)+\left(F_{3} \times 3\right)+\left(F_{4} \times 4\right)}{4}
$$

$F_{1}=$ Frekuensi responden yang menjawab 1

$F_{2}=$ Frekuensi responden yang menjawab 2

$F_{3}=$ Frekuensi responden yang menjawab 3

$F_{4}=$ Frekuensi responden yang menjawab 4 (Ferdinand, 2006)

\section{HASIL DAN PEMBAHASAN}

Sebelum dilaksanakannya pembelajaran, mahasiswa diberi angket self efficacy matematis. Hasil dari angket tersebut menjadi data awal self efficacy matematis atau pretes. Selanjutnya mahasiswa akan diajarkan dengan pembelajaran kooperatif tipe two stay two stray berbasis Autograph. Setelah melaksanakan pembelajaran mahasiswa kembali diberikan angket self efficacy (postses). Tujuannya adalah untuk mengetahui peningkatan self efficacy matematis mahasiswa sebelum dan sesudah pembelejara. Untuk mengetahui deskrpsi self efficacy matematis, peneliti menggunakan rumus nilai indeks. Hasil dari pretes dan postes self efficacy matematis dapat dirangkum dalam tabel dibawah ini. 
Tabel 2. Deskripsi Self Efficacy Matematis

\begin{tabular}{ccc}
\hline \multirow{2}{*}{ Self Efficacy } & \multicolumn{2}{c}{ Nilai Indeks } \\
\cline { 2 - 3 } & Pretes (\%) & Postes (\%) \\
\hline Indikator 1 & 70 & 72,64 \\
\hline Indikator 2 & 69,03 & 71,94 \\
\hline Indikator 3 & 73,89 & 81,39 \\
\hline Indikator 4 & 72,92 & 79,58 \\
\hline Indikator 5 & 73,44 & 80,94 \\
\hline Indikator 6 & 61,25 & 66,46 \\
\hline Indikator 7 & 66,67 & 76,46 \\
\hline Rata-Rata & 69,60 & 75,63
\end{tabular}

Berdasarkan tabel diatas dapat terlihat perbedaan nilai pretes dan postes self efficacy. Nilai indeks pretes (sebelum pembelajaran) self efficacy matematis dari indikator 1 sampai 7 berturut-turut sebesar 70\%, 69,03\%, 73,89\%, 72,92\%, 73,44\%, $61,25 \%$ dan $66,67 \%$. Sedangkan nilai indeks self efficacy matematis setelah pembelajaran (postes) pada setiap indikator secara berurut adalah 72,64\%, 71,94\%, $81,39 \%, 79,58 \%, 80,94 \%, 66,46 \%$, dan $76,46 \%$. Selanjutnya rerata nilai indeks pada pretes sebesar $69,60 \%$ dan psotes $75,63 \%$. Sehingga nilai postes lebih tinggi daripada nilai pretes. Hal ini dapat terlihat pada gambar dibawah ini.

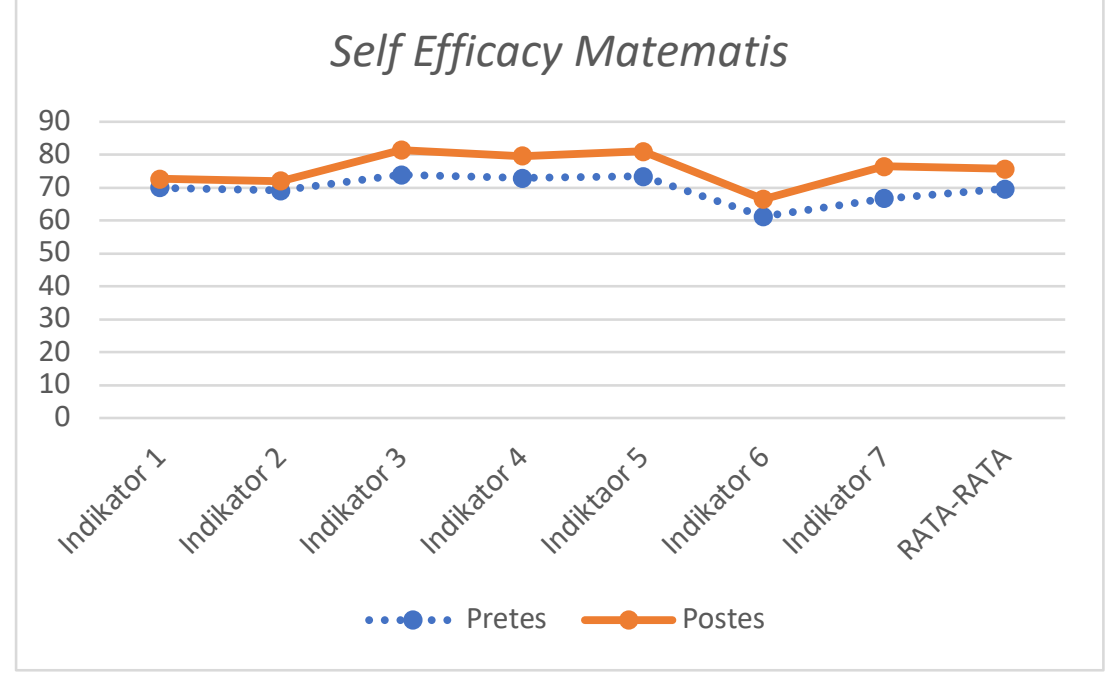

\section{Gambar 1. Grafik Self Efficacy Matematis}

Berdasarkan gambar dan penjelasan diatas, menyatakan bahwa nilai postes angket self efficacy matematis lebih tinggi daripada nilai pretes. Hal ini berarti self efficacy matematis mahasiswa sebelum dan sesudah pembelajaran mengalami peningkatan. Dengan demikian peningkatan self efficacy matematis mahasiswa diajarkan dengan pembelajaran kooperatif tipe two stay two stray berbasis Autograph.

Data yang akan di analisis adalah hasil dari angket self efficacy matematis sebelum (pretes) dan sesudah (postes) pembelajaran kooperatif tipe two stay two stray berbasis Autogrpah.. Sebelum menganalisis uji hipotesis, data angket self efficacy matematis terlebih dahulu di uji prasyarat yakni uji normalitas dan homogenitas. 
Adapun kriteria pengujian uji normalilitas, jika signifikan yang diperoleh lebih besar dari 0,05, maka sampel berasal dari populasi yang berdistribusi normal dan jika signifikan yang diperoleh lebih kecil dari 0,05 maka sampel bukan berasal dari populasi yang berdistribusi normal. Hasil perhitungan dengan IBM Statistic SPSS 23 tersajikan pada Tabel 3 berikut:

Tabel 3. Uji Normalitas Self Efficacy Matematis Tests of Normality

\begin{tabular}{lcccccc}
\hline & \multicolumn{3}{c}{ Kolmogorov-Smirnova } & \multicolumn{3}{c}{ Shapiro-Wilk } \\
\cline { 2 - 7 } & Statistic & df & Sig. & Statistic & Df & Sig. \\
\hline Pretes_SE &, 140 & 30 &, 136 &, 925 & 30 &, 037 \\
\hline Postes_SE &, 141 & 30 &, 133 &, 923 & 30 &, 032 \\
\hline
\end{tabular}

a. Lilliefors Significance Correction

Berdasarkan tabel diatas diperoleh nilai signifikan pada pretes (sebelum pembelajaran) dan postes (sesudah pembelajaran) self efficacy matematis sebesar 0,136 dan 0,133. Karena kedua data tersebut lebih besar dari 0,05, maka kedua data tersebut berdistribusi normal. sehingga uji prasyarat normalitas terpenuhi. Uji prasyarat selanjutnya adalah uji homogenitas. Kriteria pengujiannya adalah jika nilai signifikan lebih besar dari 0,05, maka varian kelompok data homogen. Sebaliknya, jika nilai signifikan lebih kecil dari 0,05 maka varian kelompok data tidak homogen. Hasil uji homogenitas dianlisis dengan IBM Statistics SPSS 23 terlihat pada tabel dibawah ini

Tabel 4. Uji Homogenitas Self Efficacy Matematis Test of Homogeneity of Variances

\section{Self_Efficacy}

\begin{tabular}{cccc}
\hline Levene Statistic & df1 & df2 & Sig. \\
\hline 1,385 & 1 & 56 &, 244 \\
\hline
\end{tabular}

Berdasarkan tabel diatas, diperoleh nilai signifikan sebesar 0,244. Karena nilai signifikan lebih besar dari 0,05, maka varian kelompok data tersebut homogeny. Sehingga uji prasyarat homogenitas pada data self efficacy matematis terpenuhi. Setelah uji prasyarat yakni uji normalitas dan homogenitas, maka selanjutnya akan menganalisis uji hipotesis dengan analisis uji t. Hasil perhitungan uji $t$ di analisis dengan IBM Statistic SPSS 23, terdapat pada tabel dibawah ini

Tabel 5. Uji t Self Efficacy Matematis Independent Samples Test

\begin{tabular}{|c|c|c|c|c|c|c|c|c|}
\hline & & $\begin{array}{l}\text { Levene } \\
\text { Equo } \\
\text { Varic }\end{array}$ & $\begin{array}{l}\text { est for } \\
\text { l of } \\
\text { ces }\end{array}$ & & $t$-test $f$ & or Equali & $y$ of Means & \\
\hline & & $\mathrm{F}$ & Sig. & T & Df & $\begin{array}{l}\text { Sig. (2- } \\
\text { tailed) }\end{array}$ & $\begin{array}{c}\text { Mean } \\
\text { Differenc } \\
e\end{array}$ & $\begin{array}{c}\text { Std. Error } \\
\text { Differenc } \\
e\end{array}$ \\
\hline SE & $\begin{array}{l}\text { Equal } \\
\text { variances } \\
\text { assumed }\end{array}$ & 1,385 & ,244 & 3,479 & 56 & ,001 & 8,87857 & 2,55209 \\
\hline & $\begin{array}{l}\text { Equal } \\
\text { variances } \\
\text { not assumed }\end{array}$ & & & 3,447 & 50,534 & ,001 & 8,97857 & 2,57559 \\
\hline
\end{tabular}


Berdasarkan tabel di atas dapat, dapat dianalisis:

1. Nilai t hitung sebesar 3,479. Dan nilai t tabel 2,003 (lihat tabel t dengan df 56). Karena nilai t hitung lebih besar dari t tabel ada perbedaan hasil angket self efficacy matematis sebelum dan sesudah pembelajaran.

2. Nilai Sig. (2-Tailed) pada tabel diatas sebesar 0,001. Karena nilai $p$ value sebesar 0,00 dan lebih kecil dari 0,05, maka terdapat perbedaan yang signifikan antara hasil angket self efficacy matematis sebelum dan sesudah pembelajaran.

3. Besarnya perbedaan rerata self efficacy mtematis sebelum dan sesudah pembelajaran sebesar 8,888. Dan nilai sesudah pembelajaran kooperatif tipe two stay two stray berbasis Autograph lebih tinggi daripada nilia sebelum pembelajaran.

Berdasarkan pemaparan diatas, dapat disimpulkan terdapat perbedaan hasil self efficacy matematis sebelum pembelajaran dan sesudah pembelajaran. Dan nilai rerata self efficacy matematis sesudah pembelajaran lebih tinggi daripada sebelum pembelajaran kooperatif tipe two stay two stary berbasis Autograph. Dengan demikian, terdapat peningkatan self efficacy matematis melalui pembelajaran kooperatif tipe two stay two stray berbasis Autograph.

\section{KESIMPULAN}

Penelitian ini berkaitan dengan pelaksanaan pembelajaran kooperatif tipe Two stay two stray berbasis Autograph terhadap self efficacy matematik mahasiswa program studi pendidikan matematika di Universitas Muslim Nusantara (UMN) Al-Washliyah. Berdasarka hasil penelitian dapat diperoleh t hitung sebesar 3,479 dan t tabel 2,003. Sehingga dapat disimpulkan, terdapat peningkatan self efficacy matematis melalui pembelajaran kooperatif tipe Two stay two stray berbasis Autograph.

\section{DAFTAR PUSTAKA}

Ananda, Y.Y.T \& Novita, D. 2018. Penerapan Model Pembelajaran Kooperatif Tipe Two Stay Two Stray Pada Materi Laju Reaksi Untuk Melatihkan Self Efficacy Siswa Kelas Kelas XI MIPA 2 SMAN 1 Blitar. Unesa Journal of Chemical Education, Vol. 7, No. 2, pp 200-207, May 2018. ISSN 2252-9454.

Ferdinand, A. 2006. Metode Penelitian Manajemen. Semarang: Universitas Diponegoro.

Istarani. 2011.58 Model Pembelajaran Inovatif. Medan : Media Persada

Jatisunda, M.G. 2017. Hubungan Self-Efficacy Siswa SMP dengan Kemampuan Pemecahan Maslah Matematis. Jurnal THEOREMS (The Original Research of Mathematics) Vol. 1 No 2, Januari 2017 Hal. 24-30.

Karnasih, I. 2008. Paper Presentated in International Workshop: ICT for Teaching and Learning Mathematics. Medan: UNIMED. (In Collaboration Between UNIMED and QED Education Kuala Lumpur). Malaysia. 
Ramadhani \& Sidabalok, S. 2018. Pengaruh Pembelajaran Kooperatif Tipe Two Stay Two Stray terhadap Self Efficacy Matematis. Artikel Prosiding Nasional Penelitian 2018 ISSN 2615-5974. LP2M Universitas Muslim Nusantar AI Washliyah Medan.

Risdianto, H. \& Karnasih, I. \& Siregar, H. 2013. The Diffrence of Enhancement Mathematical Problem Solving Ability and Self-Efficiency SMA With MA Students IPS Program Through Guided Inquiry Learning Model Assisted Autograph Software In Langsa. Jurnal Pendidikan Matematika PARADIKMA, Vol 6 Nomor 1. Hal 89-108.

Sanjaya, W. 2006. Strategi Pembelajaran Berorientasi Standar Proses Pendidikan. Jakarta : Fajar Interpersonal Offset.

Simanjuntak, M. 2017. Model Pembelajaran Kooperatif Think-Talk-Write (TTW) dan Software Autograph dalam Mempersiapkan Pendidik Matematika Menghadapi Masyarakat Ekonomi Asia (MEA). Jurnal Dinamika Pendidikan Vol. 9 No. 2. ISSN 2620-3952. www.ejournal.uki.ac.id/index.php/jdp/article/ view/339.

Subiadi, A. 2016. Self-Efficacy Siswa Dalam Pemecahan Masalah Matematika. ¿IGMA, Volume 1, Nomor 2, Maret 2016, HIm 64-68.

Sugiyono. 2017. Metode Penelitian Kuantitatif, Kualitatif dan R\&D. Bandung: Alfabeta.

Suraji \& Sari, A. 2017. Penerapan Model Kooperatif Tipe Two Stay Two Stray (TSTS) dalam Upaya Meningkatkan Kemampuan Pemecahan Masalah Siswa SD. Suska Journal of Mathematics Education (P-ISSN: 2477-4758 | e-ISSN; 25409670) Vol 3, No. 2 Hal 67-73 